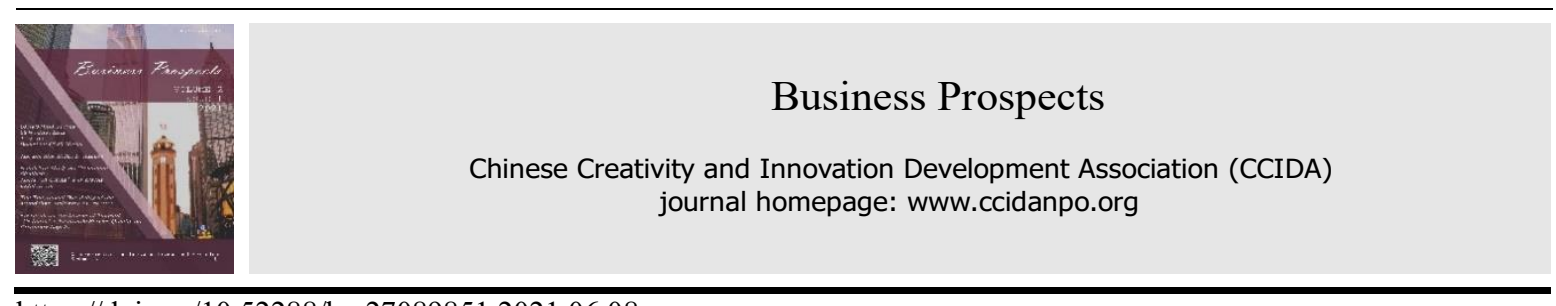

https://doi.org/10.52288/bp.27089851.2021.06.08

\title{
The Effect of Real Effective Exchange Rate Changes on China's Import Trade Structure
}

\author{
Grant G. L. Yang ${ }^{1, *} \operatorname{Amy~Li}^{2}$ \\ ${ }^{1}$ Associate Professor of School of International Business, Xiamen University Tan Kah Kee College \\ ${ }^{2}$ School of International Business, Xiamen University Tan Kah Kee College \\ * Correspondence: grant@xujc.com
}

Received:2021.03.02; Accepted:2021.03.09; Published: 2021.06.01

\begin{abstract}
The real effective exchange rate (REER) has a double effect on the value of imports. The appreciation of the real effective exchange rate directly reduces the price of imports and expands the quantity of imports, but the increase in the quantity of imports will stimulate the rise of import prices and indirectly restrain the quantity of imports. Using ADF unit root test, cointegration analysis and Granger's causality test, this paper empirically studies the relationship between the real effective exchange rate of RMB and the consumption trade imports, total trade imports and import trade structure from 1997 to 2019. The conclusion shows that the appreciation of the real effective exchange rate of RMB will reduce the total trade imports and increase the proportion of consumption trade imports, but the effect of that on consumption trade imports is not clear. Results of this study provide evidence that the price effect of RMB's real effective exchange rate is greater than the income effect of GDP growth. The price elasticity is 0.96 times the income elasticity for consumption trade imports, 2.45 for total trade imports, and 15.24 times for import trade structure.
\end{abstract}

Keywords: Real Effective Exchange Rate; Consumption Trade Imports; Total Trade Imports; Import Trade Structure

\section{Introduction}

The Chinese currency exchange rate has increasingly become the focus of the world's attention as China's trade surplus caused by its massive exports continues to expand that leads to the rapid growth of foreign exchange reserves. There is currently no consensus on the impact of changes in the real exchange rate of RMB on China's foreign trade. Although most studies believe that the appreciation of the real exchange rate of RMB will significantly reduce China's exports, there are still differences on the impact on China's imports. Wang et al. (2012) tested the short-run $J$-curve hypothesis and long-run trade balance effect of real exchange rate between China and its eighteen major trading partners. The results support the inverted $J$-curve hypothesis between China and its trading partners. However, a real appreciation of RMB has a decreasing long-run effect on China's trade balance in only three of the eighteen trading partners, while it has an increasing long-run effect in five of the eighteen trading partners. These mixed findings lead to the empirical evidence that the real appreciation of RMB has no overall long-run impact on China's trade balance.

Unlike the description in the general classical theory that the appreciation of the local currency exchange rate has led to an increase in domestic and foreign imports, there are two different opinions on the recent empirical study of China's import and export trade: one opinion is that the RMB exchange rate changes have no significant impact on China's imports, and the other holds that the appreciation of the real exchange rate of the RMB will significantly reduce China's imports. Because of the differences between theory and practice, it has become the focus of many scholars' discussion.

Studies on the impact of exchange rate appreciation on trade import and export generally do not distinguish between general trade and processing trade. In the case of currency appreciation, the reason why export trade increase rather than decrease is because of disregarding the structure of trade. Chen (2005), for example, argued 
that China's processing trade accounts for more than half of total trade. Unlike general trade, foreign companies in China's processing trade are vulnerable to the impact the appreciation of RMB. Yang (2009) believed there exists a long-term proportionate relationship between the processing trade imports and the exchange rate while the short-term dynamic effects of the appreciation of RMB on the processing trade imports are also significant. The appreciation of RMB will lead to increased processing trade imports in the short term while the effect will be proving to be counter-productive in the long run. The elasticity effects of changes in RMB exchange rate on the fluctuations of processing trade imports in both long-term and short-term is greater than 1. Jin (2011) used $\mathrm{ADF}$ test to conduct an empirical study on the relationship between RMB exchange rate and processing trade import and export from 1981 to 2010, and concluded that the rise of RMB exchange rate will reduce the growth of processing trade imports and exports.

Due to its unique trade structure and interregional economic cooperation, China's import volume decreases with the appreciation of RMB's REER, and there is a driving relationship between imports and exports. In China's trade structure, the proportion of processing trade has been more than $50 \%$, and processing trade imports are not sensitive to changes in the REER. At the same time, in China's regional economic and trade cooperation with Asian and ASEAN countries, among them, exports are more as a new division of labor and cooperation based on different divisions of labor in the production value chain, rather than just an alternative competitive relationship for overseas markets.

Bie (2012) gave an empirical analysis of the effects of RMB's REER on export trade of Shandong by employing annual data from 1990 to 2009. The result indicates that there is a long-term cointegrating combination between the change of RMB's REER and export trade of Shandong, but the elasticity is low between them, i.e., the export trade is not very sensitive to RMB's REER. The total export value in Shandong Province will only rise $0.027 \%$ if RMB's REER appreciates by $1 \%$. Li et al. (2012) believed the traditional balance-of-payments theory holds that a country's currency exchange rate changes will affect the size of the import and export and trade balance. By selecting different types of industries in China, this paper empirically tests the impact of RMB real exchange rate fluctuations on China's trade balance, and the results show that, among the factors affecting China's foreign trade, the elasticity of real exchange rate should be less than income elasticity.

The impact of RMB exchange rate fluctuations on imports and exports significantly differ in the long-term with positive impact on imports and negative impact on exports. While the fluctuation of RMB exchange rate negatively affects imports and exports in the short term, but the impact on imports is slightly greater. In the long run, the volatility of the RMB's REER can reduce the trade surplus to some extent. China's exports are mainly driven by the real income of trading partners and foreign direct investment (FDI), and are sensitive to price changes. The growth in China's imports, however, has been driven mainly by real income growth in China and is insensitive to price changes. The significant difference in the impact of exchange rate volatility on China's imports and exports reflects the deep-seated contradictions in China's economy, such as uneven domestic and foreign demand, unreasonable trade structure and trade mode.

Import demand is theoretically influenced by internal demand and the REER. Internal demand is directly related to imports, and the REER is inversely opposite to imports as a rise in exchange rates will lead to a decline in the local currency price of imported goods. Similar to exports, imports can be divided into two parts: domestic consumption or investment imports (general trade imports) and imports from processing trade. Therefore, the internal demand for processing trade production is essentially derived from the outside. Since the rise in the REER will increase general trade imports, the appreciation of the RMB exchange rate will have little impact on total imports due to the decrease in imports from processing trade as a result of the slowdown in processing trade exports.

The appreciation of the RMB will have different effects on imports from different industries and will be beneficial to China's imports of raw materials and energy products. By industry, imports of rubber, wood, pulp, wool, copper ore, plastics, crude oil and non-ferrous metals are sensitive to exchange rates. Although the total demand for these raw materials and energy products is somewhat rigid, the appreciation of the RMB exchange rate will reduce the import price of RMB, which will bring about an increase in import volume. The appreciation of the exchange rate, however, does not necessarily give rise to a significant increase in imports of manufactured goods because the import substitution effect is prominent in these products. With China's economic growth, domestic manufacturing capacity such as television sets, tape recorders, automobiles, etc. continues to improve. Some products are becoming more and more domestic and the original need to import goods are now substituted by domestic production. The import substitution effect is mainly reflected in the negative correlation between 
the import volume and the overall upward trend of economic growth rate after excluding the import volume with the economic growth factor.

Lin (2009) applied monthly data of import trades from January 1995 to December 2006 and found the appreciation of RMB's REER will significantly reduce the amount of general import rather than processing import. The results also demonstrate a strong link between China's imports and exports while exchange rate fluctuations can indirectly affect imports by affecting exports. Feng and Pei (2014) found that appreciation of RMB's REER can improve imports transformation, i.e., it can increase the imports of final consumption goods and reduce the import of intermediate products. The influence of RMB's REER volatility is not conductive to imports transformation and is stronger on the time lag of China's imports trade. As a result, the imports transformation will be a longer process.

Statistics in recent years show that the appreciation of RMB has not curbed the continuous increase in China's processing trade imports and exports, and this conclusion does not seem to be in line with the actual development of China's processing trade. This study explains the special relationship between China's imports and exchange rate by examining the influence of RMB's REER changes on the import trade structure and the composition of imported products. Data of China's consumption trade imports and total trade imports from 1997 2019 are used to investigate the effects of changes in RMB's REER and gross domestic product on the consumption trade import, total trade import and import trade structure.

\section{Consumption Import Trade and Total Import Trade}

Wei et al. (2020) have divided imports into capital goods (kimpshare), intermediate inputs (rimpshare) and consumption goods (cimpshare) according to the BEC criteria, and included the proportion of imports of these three categories of products in total imports as core explanatory variables into the measurement equation, respectively, to study the impact of the structure of imported products on economic growth. Data of China's consumption trade imports (RSIM), total trade imports (RTIM) and the proportion of RSIM to RTIM (RSTIM) from 1997 2019 are illustrated in Figure 1.

The RSIM has increased slowly since 1997 at the annual growth rate of $15.31 \%$ until 2014. The growth rates are close to zero between 2015 and 2019, which reduces the average annual growth rate for the period to $11.87 \%$. The time trend of RTIM, however, appears relatively inconsistent among these periods showing threesegment fluctuations. The first paragraph continued to increase at an annual growth rate of $18.91 \%$ from 1997 to 2008. After the import shock caused by the global financial crisis in 2008, the second phase grew at an average annual growth rate of $10.76 \%$ from 2009 to 2014 . While the third phase of import growth slowed relatively, with an average annual growth rate of $3.25 \%$ from 2015 to 2019 , resulting in an average annual growth rate of $10.84 \%$ for RTIM in recent 22 years.

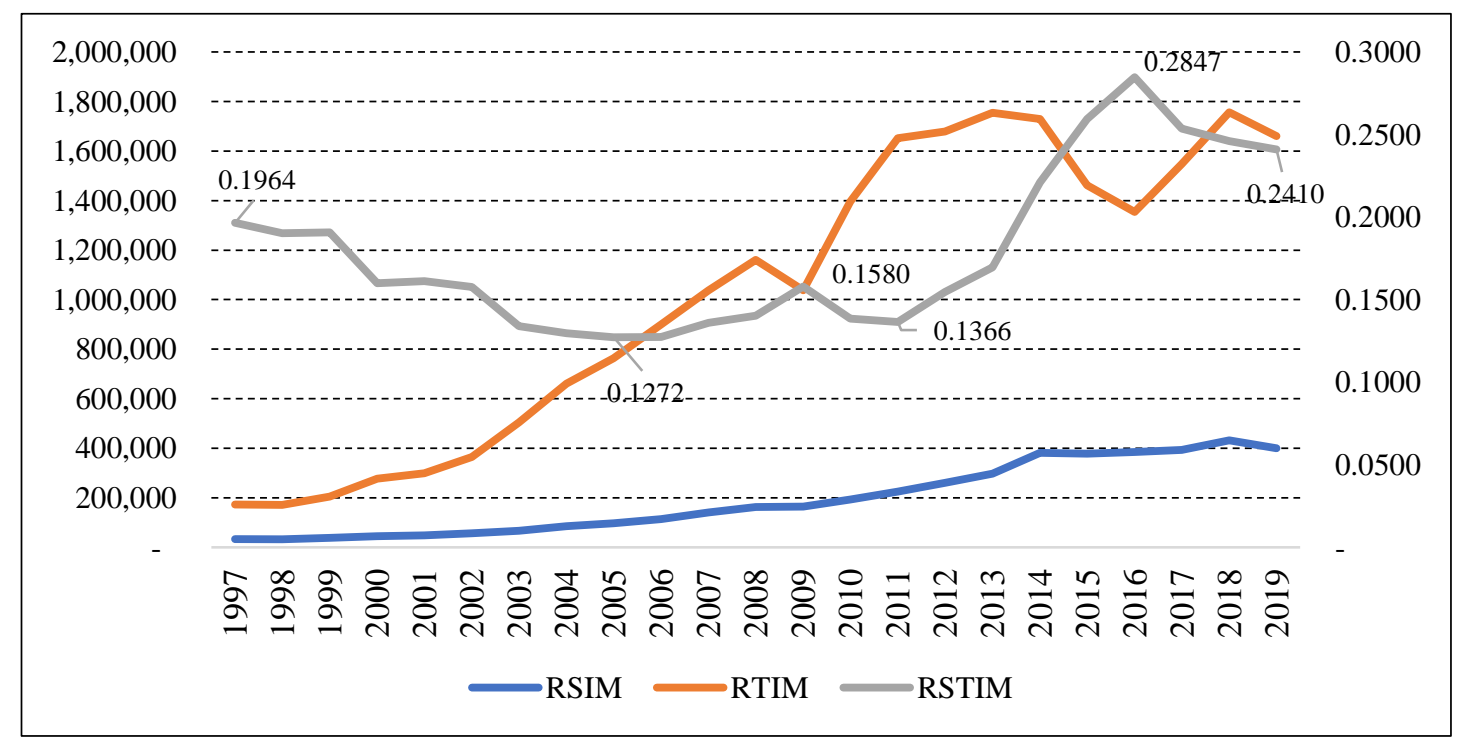

Figure 1. China's consumption trade imports (RSIM), total trade imports (RTIM) and the proportion of RSIM to RTIM (RSTIM) from 1997 2019. 
The import trade structure defined as the proportion of RSIM to RTIM (RSTIM) from 1997 2019 fluctuates because of the inconsistence of RTIM among these periods, especially in the period of 2014 2016. There are some reasons for the variation of imports. First, the sharp fall in international commodity prices has led to a decline in commodity imports. The slow global economic recovery, weak demand for commodities, and the release of investment-building capacity during the period of high commodity prices in previous years have gave rise to an overall oversupply of energy-resource commodities and a continued decline in prices. From January to September 2015, the Dow Jones Futures Index (DJAIG), the Reuters/Jefferies Commodity Research Bureau Index (RJ/CRB) and the S.P.-Goldman Sachs Commodity Index (GSCI) fell 16\%, 15.2\% and 18.9\%, respectively. A sharp drop that deepened from a year earlier is the main reason for the sharp drop in Chinese imports.

Second, the sharp fall in the prices of the world's major commodities is in fact evidence of the slow recovery in the world economy and weak demand. As China's economy enters the new stage, the domestic economy is under greater pressure of economic slowdown, and the growth rate of some commodity imports has slowed. In 2015 , China's crude oil imports increased by $8.8 \%$, iron ore imports increased by $2.2 \%$, while imports of coal, copper and steel decreased by $29.9 \%, 0.3 \%$ and $11.4 \%$, respectively, all of which fell in varying degrees from the previous year (Ministry of Commerce, 2016). Therefore, the sharp decline in global commodity prices and the slowdown in the growth rate of commodity imports are important reasons for the decline in the value of China's imports in 2015.

Third, the deep adjustment of the economic structure has weakened the demand for traditional Chinese imports from strong to weak. China is in a new stage of transformation and upgrading, with the rapid development of strategic emerging industries and services. The growth rate of traditional manufacturing, energy-intensive and high-polluting industries has slowed down as well the growth rate of investment on these industries, which results in a sharp decline in the growth rate of imports of energy resources products, and some even a relatively large decline. For example, iron ore imports increased at zero year-on-year, while imports of steel, unforged copper and copper, and metalworking machine tools decreased by $11.6 \%, 5.5 \%$ and $16.8 \%$, respectively (Ministry of Commerce, 2016).

Finally, the export production of processing trade continued to be depressed resulting in the imports of raw materials and components continued to decline. China's export processing trade accounted for more than $30 \%$ of total trade exports, which is characterized with massive import and export quantity, resulting in a considerable part of China's imports are intermediate products needed by export production. In face of low international market demand and fierce competition, China's processing trade exports continued to decline by $8.8 \%$, and imports of processing trade fell by $13.8 \%$.

\section{Time Trend Analysis}

According to the different characteristics of REER and RGDP, this study distinguishes the impact of the two on China's consumption trade import, total trade imports and import trade structure. Because of the relationship between the variables applied in this study, the linear regression method usually cannot make an effective estimate of the causal relationship between variables. The unlimited vector autoregression model (VAR) is used to test and analyze, and the VAR model is established:

$$
Y_{t}=\alpha_{0}+\alpha_{1} Y_{t-1}+\alpha_{2} Y_{t-2}+\cdots+\alpha_{p} Y_{t-p}+\varepsilon_{t} \quad \mathrm{t}=1, \ldots, \mathrm{T}
$$

where $Y_{t}=(R S I M, R T I M, R S T I M, R E E R, R G D P)$. Since the VAR model requires the system to be stable, the ADF stability of each variable is tested first followed by the Johansen cointegration test method for the longterm cointegrated relationship between the variables. Finally, the impulse response effect is analyzed.

\subsection{Stability Tests}

The EViews 10.0 software is used to carry out stability test on the dependent and independent variables for unit root tests. By observing the line chart, some variables have intercept items and Augmented DickeyFuller (ADF) test forms include intercept items. The lag length is automatically determined according to the $\mathrm{AIC} / \mathrm{SC}$ information guidelines (Table 1). Tests for unit root are in $1^{\text {st }}$ difference for all variables as the I (1) process except RGDP, that is, the corresponding first-order differential values for most variables are smooth process. 


\subsection{Co-integration Tests}

Co-integration exists only when two variables follow the same time series process, or the time series process of dependent variable is no more than the independent variables. Unit root tests show that all variables follow I (1) process except RGDP and the Johansen co-integration tests of trace statistic and maximum Eigen statistic can be applied in this study for the results illustrated in Table 2a to Table 2c for RSIM, RTIM, and RSTIM, respectively.

Table 1. Unit root test results for all variables.

\begin{tabular}{ccccc}
\hline Variables & $\begin{array}{c}\text { Test type } \\
(\mathbf{C}, \mathbf{T}, \mathbf{K})^{*}\end{array}$ & ADF-statistic & $\begin{array}{c}\text { Test critical value } \\
(\mathbf{5 \%} \text { level })\end{array}$ & Conclusion \\
\hline RSIM & $(0,0,2)$ & 0.6349 & -1.9591 & Not stable \\
RTIM & $(0,0,2)$ & 0.9180 & -1.9591 & Not stable \\
RSTIM & $(0,0,1)$ & 0.0410 & -1.9581 & Not stable \\
REER & $(\mathrm{C}, \mathrm{T}, 1)$ & -2.3444 & -3.6450 & Not stable \\
RGDP & $(\mathrm{C}, \mathrm{T}, 0)$ & -3.8308 & -3.6329 & Stable \\
\hline$\Delta$ RSIM & $(\mathrm{C}, 0,0)$ & -3.7734 & -3.0124 & Stable \\
$\Delta$ RTIM & $(\mathrm{C}, 0,1)$ & -3.6301 & -3.0207 & Stable \\
$\Delta$ RSTIM & $(\mathrm{C}, 0,3)$ & -3.9150 & -3.6908 & Stable \\
$\Delta$ REER & $(0,0,1)$ & -2.6949 & -1.9591 & Stable \\
\hline
\end{tabular}

${ }^{*} \mathrm{C}$ denotes intercept; $\mathrm{T}$ denotes trend; $\mathrm{K}$ denotes lag length

Results of Johansen's Maximum Eigen Statistic and Trace Statistic in Table 2 demonstrate that there is at least one co-integrated relationship between RTIM, REER, and RGDP. The unit root test of non-equilibrium error is carried out at the same time that the obedience to I (0) process is stable, which further confirms the existence of co-integration relationship in the sequence. For RSIM and RSTIM, however, the Johansen cointegration tests cannot reject the hypothesis of no co-integration.

Table 2a. Johansen co-integration tests (RSIM, REER, RGDP).

\begin{tabular}{ccccccc}
\hline $\begin{array}{c}\text { Hypothesized } \\
\text { No. of CE(s) }\end{array}$ & $\begin{array}{c}\text { Trace } \\
\text { Statistic }\end{array}$ & $\begin{array}{c}\mathbf{5 \%} \text { Critical } \\
\text { Value }\end{array}$ & Pro.* $^{* *}$ & $\begin{array}{c}\text { Max-Eigen } \\
\text { Statistic }\end{array}$ & $\begin{array}{c}\mathbf{5 \%} \text { Critical } \\
\text { Value }\end{array}$ & Prob.** $^{*{ }^{* *}}$ \\
\hline None & 18.7297 & 29.7971 & 0.5125 & 10.4536 & 21.1316 & 0.7013 \\
At most 1 & 8.2762 & 15.4947 & 0.4363 & 7.5456 & 14.2646 & 0.4268 \\
At most 2 & 0.7306 & 3.8415 & 0.3927 & 0.7306 & 3.8415 & 0.3927 \\
\hline
\end{tabular}

Table 2b. Johansen co-integration tests (RTIM, REER, RGDP).

\begin{tabular}{ccccccc}
\hline $\begin{array}{c}\text { Hypothesized } \\
\text { No. of CE(s) }\end{array}$ & $\begin{array}{c}\text { Trace } \\
\text { Statistic }\end{array}$ & $\begin{array}{c}\mathbf{5 \%} \text { Critical } \\
\text { Value }\end{array}$ & Pro. $^{* *}$ & $\begin{array}{c}\text { Max-Eigen } \\
\text { Statistic }\end{array}$ & $\begin{array}{c}\mathbf{5 \%} \text { Critical } \\
\text { Value }\end{array}$ & Prob. $^{* *}$ \\
\hline None $^{*}$ & 32.1594 & 29.7971 & 0.0262 & 15.7663 & 21.1316 & 0.2388 \\
At most $1^{*}$ & 16.3931 & 15.4947 & 0.0365 & 13.4440 & 14.2646 & 0.0671 \\
At most 2 & 2.9492 & 3.8415 & 0.0859 & 2.9492 & 3.8415 & 0.0859 \\
\hline
\end{tabular}


Table 2c. Johansen co-integration tests (RSTIM, REER, RGDP).

\begin{tabular}{ccccccc}
\hline $\begin{array}{c}\text { Hypothesized } \\
\text { No. of CE(s) }\end{array}$ & $\begin{array}{c}\text { Trace } \\
\text { Statistic }\end{array}$ & $\begin{array}{c}\mathbf{5 \%} \text { Critical } \\
\text { Value }\end{array}$ & Pro. $^{* *}$ & $\begin{array}{c}\text { Max-Eigen } \\
\text { Statistic }\end{array}$ & $\begin{array}{c}\mathbf{5 \%} \text { Critical } \\
\text { Value }\end{array}$ & Prob.*** $^{* *}$ \\
\hline None & 19.7796 & 29.7971 & 0.4379 & 12.2475 & 21.1316 & 0.5234 \\
At most 1 & 7.5320 & 15.4947 & 0.5167 & 4.8374 & 14.2646 & 0.7622 \\
At most 2 & 2.6946 & 3.8415 & 0.1007 & 2.6946 & 3.8415 & 0.1007 \\
\hline
\end{tabular}

${ }^{*}$ denotes rejection of the hypothesis at the 0.05 level

** MacKinnon-Haug-Michelis (1999) p-values

\subsection{Granger's Causality Tests}

The co-integration tests have demonstrated a long-term equilibrium relationship between RTIM, REER, and RGDP, and the Granger's causality tests are necessary to further verify the relationship between the causes and effects. Table 3 validates that the causality exists for REER and RSTIM in one to three lagged periods only, and it is also true for RGDP and RSTIM in one lagged period. The Granger causality tests do not hold for REER and RGDP for RSIM and RTIM for all lagged periods. The results suggest that REER and RGDP affect RSTIM, while the impact of real effective exchange rates and real gross domestic product on consumption trade imports and total trade imports are uncertain.

Table 3. Granger causality tests.

\begin{tabular}{ccccc}
\hline Null Hypothesis & $\begin{array}{c}\text { Lags to } \\
\text { include }\end{array}$ & F-Statistic & Prob. & Result \\
\hline REER does not Granger Cause RSIM & & 0.2950 & 0.5934 & Not Reject \\
RGDP does not Granger Cause RSIM & & 3.7441 & 0.0680 & Not Reject \\
REER does not Granger Cause RTIM & 1 & 1.3580 & 0.2583 & Not Reject \\
RGDP does not Granger Cause RTIM & & 0.0253 & 0.8754 & Not Reject \\
REER does not Granger Cause RSTIM & & 15.9004 & 0.0008 & Reject \\
RGDP does not Granger Cause RSTIM & & 5.7804 & 0.0266 & Reject \\
\hline REER does not Granger Cause RSIM & & 0.2251 & 0.8009 & Not Reject \\
RGDP does not Granger Cause RSIM & & 1.9274 & 0.1778 & Not Reject \\
REER does not Granger Cause RTIM & 2 & 2.6924 & 0.0982 & Not Reject \\
RGDP does not Granger Cause RTIM & & 2.9105 & 0.0836 & Not Reject \\
REER does not Granger Cause RSTIM & & 8.3693 & 0.0033 & Reject \\
RGDP does not Granger Cause RSTIM & & 3.0279 & 0.0767 & Not Reject \\
\hline REER does not Granger Cause RSIM & & 0.2107 & 0.8872 & Not Reject \\
RGDP does not Granger Cause RSIM & & 0.8290 & 0.1916 & Not Reject \\
REER does not Granger Cause RTIM & & 1.4003 & 0.2871 & Not Reject \\
RGDP does not Granger Cause RTIM & 3 & 1.3638 & 0.2974 & Not Reject \\
REER does not Granger Cause RSTIM & & 9.5946 & 0.0013 & Reject \\
RGDP does not Granger Cause RSTIM & & 2.8822 & 0.0763 & Not Reject \\
\hline
\end{tabular}

Unit root tests and co-integration tests prove the existence of co-integration relationship among non-stable variables in this study followed by the Granger causality tests for the demonstration of causes and effects. The causality equation can be expressed as:

$$
\begin{gathered}
\text { RSIM }=-659.6244 \text { REER }+0.037779 \text { RGDP } \\
\text { RTIM }=375.3029 \text { REER }+0.141005 \text { RGDP } \\
\text { RSTIM }=0.001572 \text { REER + 2.72E-09RGDP }
\end{gathered}
$$


The equation demonstrates that there is a negative correlation between real effective exchange rate and consumption trade imports, and a positive correlation between real gross domestic product and consumption trade imports. For the cases of total trade imports and import trade structure, however, the causality equations demonstrate positive impact from both real effective exchange rate and real gross domestic product.

\section{Analysis of Impulse Response Effect}

The impulse response function is used to measure the system's response to a variable being hit, and only the effects of REER and RGDP on RSIM and RTIM are observed here (Figures 2 and 3). The results of the impulse show that real effective exchange rate has a positive impact on consumption trade imports and total trade imports with sustained stability over time. Its effect has weakened but by the 10th phase can still have a positive impact on the trade imports. The role of real effective exchange rate in promoting consumption trade imports only appears in the initial stage, and declines gradually after phase 2 . The impact gradually decreases by about 10 periods but still has a long-term and sustained effect. The role of real effective exchange rate in promoting total trade imports starts slowly and declines gradually after phase 7 . The impact gradually decreased by about 10 periods but still has a long-term and sustained effect. In terms of the magnitude of change, consumption trade imports are more sensitive than total trade imports to real effective exchange rate.

The results of the impulse in Table 3 show that real gross domestic product has a negative impact on consumption trade imports and total trade imports with sustained stability over time. Its effect has strengthened and can still have a positive impact after 10th phase for consumption trade imports. The role of real gross domestic product in affecting total trade imports only appears in the first $7 \sim 8$ stages, and declines gradually after phase 9 . In terms of the magnitude of change, consumption trade imports are more sensitive than total trade imports to real gross domestic product.

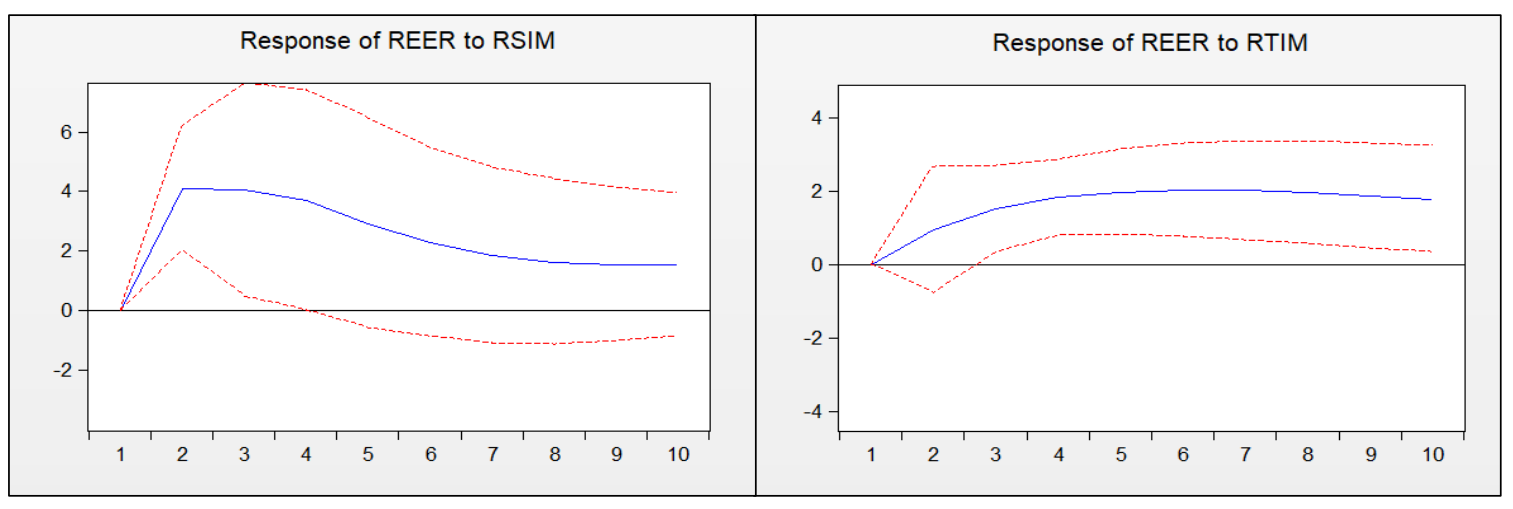

Figures 2. Impulse response of REER to RSIM and RTIM.

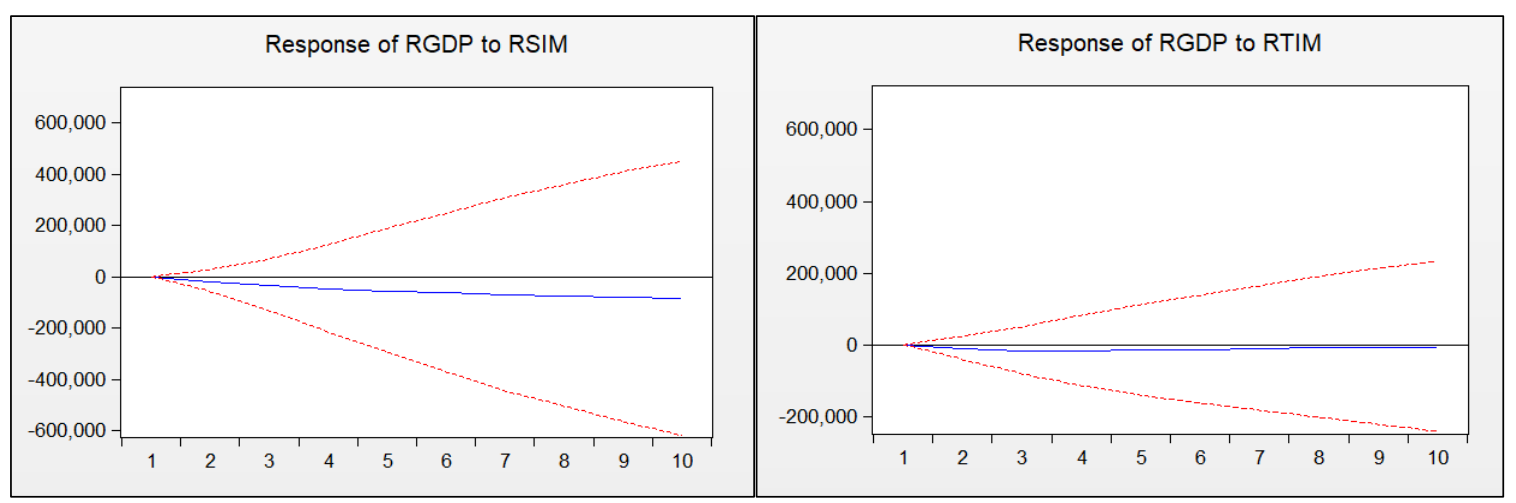

Figures 3. Impulse response of RGDP to RSIM and RTIM.

\section{Empirical Results}

The model results are presented in Table 4 for RSIM, RTIM, and RSTIM. The regression results of RSIM show that one-period lag is positively related to current RSIM. In fact, the lagged RSIM is an important indicator 
of consumption trade imports and is positively related to the consumption of the economy. The one-period lagged RSIM contributes to $20 \%$ of current consumption trade imports. REER in this model indicates a positive impact on RSIM, representing a one unit increase in REER results in 1,500 units increases in RSIM. Coupled with 0.0242 unit increases in RSIM caused by one unit increase in RGDP, the model demonstrates plausible effects from price and income to consumption trade imports.

The regression results of RTIM show that one-period lag is positively related to current RTIM as well. In fact, the lagged RTIM is an important indicator of total trade imports and is positively related to the import of the economy. The one-period lagged RTIM contributes to nearly $90 \%$ of current total trade imports. REER in this model indicates a negative impact on RTIM, representing a one unit increase in REER results in 12,897 units decreases in RTIM. Coupled with 0.0514 unit increases in RTIM caused by one unit increase in RGDP, the model demonstrates plausible effects that are consistent to literature (Pan, 2018).

Table 4. Empirical results of RSIM, RTIM, RSTIM.

\begin{tabular}{cccc}
\hline Variables & RSIM & RTIM & RSTIM \\
\hline C & $-165,394$ & $1,136,825$ & -0.1409 \\
(t-statistic) & $(-1.7242)$ & $(3.6274)^{* *}$ & $(-3.7445)^{* *}$ \\
Lagged (-1) & 0.2059 & 0.8925 & 0.5999 \\
& $(0.6651)$ & $(7.9799)^{* *}$ & $(6.7609)^{* *}$ \\
REER & $1,500.91$ & $-12,896.78$ & 0.0023 \\
& $(1.5280)$ & $(-3.3219)^{* *}$ & $(4.3507)^{* *}$ \\
RGDP & 0.0242 & 0.0514 & $-2.76 \mathrm{E}-09$ \\
& $(2.6550)^{*}$ & $(2.3580)^{*}$ & $(-1.6510)$ \\
\hline$R^{2}$ & 0.9823 & 0.9653 & 0.9388 \\
$\bar{R}^{2}$ & 0.9793 & 0.9595 & 0.9286 \\
D-W & 1.4747 & 1.8783 & 1.9221 \\
\hline
\end{tabular}

\footnotetext{
* denotes rejection of the hypothesis at the 0.05 level
}

${ }^{* *}$ denotes rejection of the hypothesis at the 0.01 level

The registration results of RSTIM show that one-period lag is positively related to current RSTIM as well. In fact, the lagged RSTIM is an important indicator of import trade structure and is positively related to the import trade structure of the economy. The one-period lagged RSTIM contributes to nearly $60 \%$ of current import trade structure. REER in this model indicates a positive impact on RSTIM, representing a one unit increase in REER results in 0.0023 units increases in RSTIM. The effect of increases in RGDP, however, is less sensitive to the import trade structure with nearly no effect on import trade structure.

The log-form model results are presented in Table 5 for $\operatorname{Ln}(\mathrm{RSIM}), \mathrm{Ln}$ (RTIM), and $\mathrm{Ln}$ (RSTIM) on the elasticity estimation of price effect and income effect. The regression results of $\operatorname{Ln}(\mathrm{RSIM})$ show that one-period lag is positively related to current RSIM. The elasticity of lagged RSIM is 0.6938 , demonstrating a $1 \%$ change in lagged RSIM resulting in $0.6938 \%$ increases in current consumption trade imports. The result is consistent to lagged RTIM for a $1 \%$ change in lagged RTIM resulting in $0.6775 \%$ increases in current total trade imports. For a $1 \%$ change in REER in this model will result in $0.49 \%$ and $1.44 \%$ decrease in RSIM and RTIM, respectively. The results demonstrate the price elasticities of changes in real effective exchange rate to RSIM and RTIM are 0.49 and 1.44, and the latter is about three times the former. For a $1 \%$ change in RGDP in this model will result in $0.5124 \%$ and $0.5877 \%$ increases in RSIM and RTIM, respectively. The results demonstrate the income elasticities of changes in real gross domestic product to RSIM and RTIM are 0.5124 and 0.5877 , and there is no significant difference between the two.

The log-form regression results of RSTIM show that one-period lag is positively related to current RSTIM as well. The elasticity of lagged RSTIM is 0.5575 , demonstrating a $1 \%$ change in lagged RTSIM resulting in $0.5575 \%$ increases in current imports structure, and is relatively less sensitive compared to RSIM and RTIM. REER in this model indicates a positive impact on RSTIM, representing a 1\% increase in REER results in $1.2177 \%$ increases in RSTIM. The positive effects of changes in price on import trade structure also indicate the consumption trade imports is relatively stable and inflexible to price change. Coupled with only $0.0799 \%$ decreases in RSTIM caused by $1 \%$ change in RGDP, the model demonstrates plausible effects that are consistent with literature for a relatively stable import trade structure. 
Results of Table 5 in this study also provide evidence that the price effect of RMB's real effective exchange rate is greater than the income effect of GDP growth. The price elasticity is 0.96 times the income elasticity for consumption trade imports $(0.4916 / 0.5124), 2.45$ times for total trade imports $(1.4424 / 0.5877)$, and 15.24 times for import trade structure (1.2177/0.0799).

Table 5. Empirical results of log forms of RSIM, RTIM, RSTIM.

\begin{tabular}{cccc}
\hline Variables & Ln(RSIM) & Ln(RTIM) & Ln(RSTIM) \\
\hline C & -2.0128 & 1.9631 & -5.1592 \\
(t-statistic) & $(-0.6067)$ & $(2.4819)^{*}$ & $(-5.3195)^{* *}$ \\
Ln(Lagged (-1)) & 0.6938 & 0.6775 & 0.5575 \\
& $(2.6108)^{*}$ & $(6.4739)^{* *}$ & $(5.6449)^{* *}$ \\
Ln(REER) & -0.4916 & -1.4424 & 1.2177 \\
Ln(RGDP) & $(-2.1955)^{*}$ & $(-4.4968)^{* *}$ & $(4.1427)^{* *}$ \\
& 0.5124 & 0.5877 & -0.0799 \\
$R^{2}$ & $(1.3019)$ & $(3.1334)^{* *}$ & $(-1.5489)$ \\
$\bar{R}^{2}$ & 0.9932 & 0.9884 & 0.9372 \\
D-W & 0.9921 & 0.9865 & 0.9267 \\
\hline
\end{tabular}

${ }^{*}$ denotes rejection of the hypothesis at the 0.05 level

${ }^{* *}$ denotes rejection of the hypothesis at the 0.01 level

\section{The Impact of Real Effective Exchange Rate on Import Trade}

This study finds that the appreciation of the real effective exchange rate of RMB will lead to a decrease in consumption trade imports and total trade imports at the same time, while China's total trade imports are more sensitive to fluctuations in the real effective exchange rate of RMB. In contrast to China's consumption trade imports are relatively unaffected by the real effective exchange rate fluctuations of RMB, the import trade structure shown by the proportion of consumption imports is increased. Estimation results of this study also provide evidence that the price effect of RMB's real effective exchange rate is greater than the income effect of GDP growth for total trade imports and import trade structure rather than consumption trade imports.

Through the model analysis, it is found that the appreciation of the real effective exchange rate of RMB will significantly reduce the total trade imports, which is due to China's regional trade patterns with other Asian countries. With the gradual transfer of China's production structure to the upstream of the value chain and the establishment of the world factory status, China's exports to Asian countries are no longer simple competition and substitution relations, but gradually transformed into division of labor and cooperative relations. China imports energy, raw materials, semi-finished products, spare parts, machinery and equipment as a source of raw materials to the vast number of Asian countries, and exports them to the European and American markets through processing and assembly at home, which is also the main regional trade model between China and Asian countries. Since China imports raw materials and primary products from Asian countries in the industrial value chain, it processes and produces them domestically and eventually exports them to markets in Europe and the United States. With the appreciation of the real effective exchange rate of RMB, China's exports to Europe and the United States will be significantly reduced, and China's import demand for fuel, raw materials, and machinery transportation equipment and other products related to this export production will be reduced. The link of China's exports with domestic imports reflects in the role of China's exports in promoting imports. The appreciation of RMB exchange rate indirectly affects China's import volume by affecting China's exports, and imports are then reduced with the appreciation of the real effective exchange rate.

Finally, with the development of China's economy and the deepening of marketization, the appreciation of the real effective exchange rate of RMB will reduce China's imports and exports at the same time. Relying solely on RMB exchange rate adjustment cannot effectively affect the trade surplus brought about by processing trade, and the impact of RMB exchange rate adjustment on China's overall trade surplus needs to be further studied. 


\section{Reference}

1. Bie, X. W. (2012). An Empirical Analysis of the Effect of RMB's Real Effective Exchange Rate on Export Trade-based on Shandong Province's Statistic Data. International Institute of Statistics \& Management Engineering Symposium. School of Economics Shanghai University, Shanghai, P. R. China, 200444: 592-596.

2. Chen, Z. Z. (2005). The Influence of the Upvaluation of RMB on the Full Foreign-owned Enterprises of the Processing Trade in Mainland China. SCI/TECH Information Development \& Economy, 15(9): 117-120.

3. Feng, Y. G., \& Pei, X. Y. (2014). The Effect of Imports Transformation Caused by RMB Real Effective Exchange Rate Changes. World Economy Study, 3: 21-26.

4. Jin, X. F. (2011). An Empirical Study on the Impact of RMB Real Exchange Rate on China's Processing Trade-Based on the Annual Data from 1981-2010. Times Finance, 10Z: 7-8+15.

5. Li, H., He, M. B., \& Qian, L. (2012). The Effect of RMB Exchange Rate on Trade Balance in Different Industries in China. Journal of Tianjin Normal University (Social Science), 1: 67-71.

6. Lin, Y. (2009). An Empirical Study on the Impact of RMB Real Effective Exchange Rate on China's Import Trade. Huabei Finance, 3: 10-13.

7. Pan, S. (2018). The Impact of RMB Exchange Rate Fluctuation on Price Level in China: An Empirical Analysis Based on the Vector Error Correction Model. International Journal of Economics and Finance, 10(5): 184-196.

8. Wang, C. H., Lin, C. H. A., \& Yang, C. H. (2012). Short-run and Long-run Effects of Exchange Rate Change on Trade Balance: Evidence from China and Its Trading Partners. Japan and the World Economy, 24(4): 266-273.

9. Wei, H., Wang, C. N., \& Li, M. Y. (2020). Import Structure and Economic Growth: Evidence from the World. Forum of World Economics \& Politics, 4: 77-103.

10. Yang, B. Y. (2009). An Empirical Study of the Impact of RMB Exchange Rate Variation on China's Processing Trade Import: 1995-2008. Contemporary Finance \& Economics, 9(298): 99-104.

(Editors: Yuxi Lin \& Airtok Lin) 